This is an electronic reprint of the original article. This reprint may differ from the original in pagination and typographic detail.

Author(s): Pankakoski, Timo

Title: $\quad$ Containment and intensification in political war : Carl Schmitt and the Clausewitzian heritage

Year: $\quad 2017$

Version:

Please cite the original version:

Pankakoski, T. (2017). Containment and intensification in political war : Carl Schmitt and the Clausewitzian heritage. History of European Ideas, 43(6), 649-673.

https://doi.org/10.1080/01916599.2016.1234967

All material supplied via JYX is protected by copyright and other intellectual property rights, and duplication or sale of all or part of any of the repository collections is not permitted, except that material may be duplicated by you for your research use or educational purposes in electronic or print form. You must obtain permission for any other use. Electronic or print copies may not be offered, whether for sale or otherwise to anyone who is not an authorised user. 


\section{Containment and intensification in political war: Carl Schmitt and the Clausewitzian}

heritage

Timo Pankakoski

History of European Ideas 43:6, 2017, 649-673.

https://doi.org/10.1080/01916599.2016.1234967

[Accepted manuscript version]

\section{Introduction}

In 1927, Carl Schmitt noted that war was not 'the continuation of politics by other means. ${ }^{1}$ In 1936, however, war was for him 'a continuation of political interaction with the involvement of other means'. ${ }^{2}$ Finally, in 1963 Schmitt claimed that the idea of war as the continuation of politics contained the dangerous logic of partisan warfare that he largely rejected. ${ }^{3}$ While the first and third

${ }^{1}$ Carl Schmitt, 'Der Begriff des Politischen', Archiv für Sozialwissenschaft und Sozialpolitik, 58 (1927), 1-33 (8).

${ }^{2}$ Carl Schmitt, 'Politik', [1936], in Staat, Großraum, Nomos: Arbeiten aus den Jahren 1916 bis 1969 (hereafter SGN), ed. Günter Maschke (Berlin, 1995), 133-8 (137).

${ }^{3}$ Carl Schmitt, Theory of the Partisan: Intermediate Commentary on the Concept of the Political, translated by G. L. Ulmen (New York: Telos Press Publishing, 2007[1963]); 8; Carl Schmitt, Theorie des Partisanen: Zwischenbemerkung zum Begriff des Politischen (Berlin, 2006[1963]), 15. I make references to English editions, whenever available, and give page numbers for the German editions in brackets. All translations are my own. 
statements are roughly compatible, both clash with the second. How are we to make sense of these contradictions?

Schmitt obviously referred to Carl von Clausewitz who considered war 'a genuine political instrument, a continuation of political intercourse, a carrying out of the same with other means' and 'nothing but a continuation of political interaction with the involvement of other means' ${ }^{4}$ But what should we make of the relationship between the two thinkers in general, as reflected particularly in Schmitt's remarkably inconsistent notes on the famous Clausewitzian dictum? As scholars are generally unaware of Schmitt's 1936 statement, the problem of his ambiguous reception of Clausewitz remains mostly untreated; the prevailing view is that Schmitt simply discarded Clausewitz. This article provides the first full-scale chronological analysis of Schmitt's relation to Clausewitz, advancing a more nuanced interpretation. This is not merely of scholarly importance, given that both thinkers' ideas emerge in contemporary debates on new forms of war and security threats. If we wish to understand the phenomenon of political war, we must comprehend the tradition in which it was theorised and grasp its logic correctly.

I argue that Schmitt's theory of war oscillates between two poles, which I call 'containment' and 'intensification'. Rather than substantial arguments in themselves, these are analytical categories that enable the classification of arguments. 'Containment' arguments seek to de-escalate conflicts or observe limiting tendencies, such as balance of power or the criminalisation of particular forms of war, while 'intensification' arguments either identify or propose contrary elements, such as the rise of popular warfare or the linking of war with political ideologies. There are extensive parallels

\footnotetext{
${ }^{4}$ Carl von Clausewitz, On War. Ed. Michael Howard \& Peter Paret (Princeton, 1989), 87, 605; Carl von Clausewitz, Vom Kriege: Hinterlassenes Werk (Frankfurt am Main, 1980 [1832]), 34, 674.
} 
between Clausewitz and Schmitt as regards both argument types. First, by situating Schmitt's remarks in their contexts, I argue that his idea of political war may be read as a radicalised version of Clausewitz's theory rather than a strict deviation and, second, that this is so precisely because of the tension between containment and intensification-something identifiable already in Clausewitz.

The general literature on Clausewitz and Schmitt individually is vast, but links between the two debates are rare. This is not to say that the earlier, somewhat fragmented literature does not provide useful starting points. ${ }^{5}$ However, due to insufficient attention to contextual chronology, scholarship tends to conflate Schmitt's reception of Clausewitz into a single position instead of seeing it as a process. Some scholars take The Concept of the Political as the point of entry, ${ }^{6}$ while others start with Schmitt's late Theory of the Partisan. ${ }^{7}$ Both approaches risk overemphasising ${ }^{5}$ Günter Meuter ('Lob der Feindschaft: Carl Schmitts Sinngebung des Krieges', in Krieg -
Instrument der Politik? Bewaffnete Konflikte im Übergang vom 20. zum 21. Jahrhundert [BadenBaden, 2002], 393-444 [396-7]) briefly noted the parallel between Clausewitz and Schmitt as regards the political nature of war and Schmitt's changing positions vis-à-vis Clausewitz's dictum between 1927 and 1936. Erich Vad (Strategie und Sicherheitspolitik: Perspektiven im Werk von Carl Schmitt [Opladen, 1996], 116-28) brought up their parallel starting points and Schmitt's gradual deviation from Clausewitz's classical perspective.

${ }^{6}$ Beatrice Hanssen, Critique of Violence: Between Poststructuralism and Critical Theory (London, 2000), 23; James Dodd, Violence and Phenomenology (New York, 2009), 20-45.

${ }^{7}$ In his comprehensive account of Clausewitz's twentieth-century relevance, Raymon Aron, for instance, only comments upon Schmitt's explicit treatment of Clausewitz in the partisan theory and bypasses the wider influence. See Raymond Aron, Clausewitz: Philosopher of War, translated by Christine Booker and Norman Stone (New York, 1986[1976]), 363-371. Dan Diner correctly 
intensification or even identifying Schmitt's position altogether with such arguments. If containment arguments are neglected, Schmitt also seems to belong to the twentieth-century ideological distortion of Clausewitz, in which the primacy of political considerations was reversed in favour of the military. ${ }^{8}$ I seek to show that this is largely a misconception.

notes the similarity between Clausewitz's framework and Schmitt's theory of contained war, but, with Theory of the Partisan excessively directing his reading, tends to reduce the complexity of the Schmitt/Clausewitz relation to what I call the intensification argument, arguing for instance that only antagonistic and revolutionary wars were for Schmitt 'true wars.' See Dan Diner, 'Anerkennung und Nichtanerkennung: Über den Begriff des Politischen in der gehegten und antagonistischen Gewaltanwendung bei Clausewitz und Carl Schmitt', in Clausewitz in Perspektive: Materialen zu Carl von Clausewitz: Vom Kriege, ed. Günter Dill (Frankfurt am Main, 1980), 447-64. In a recent article, Dirk Blasius briefly compiles Clausewitz's observations on the history of partisanship in Prussia, Lenin's and Mao's reception of Clausewitz, and Schmitt's rendering of these links in the 1960s, thus going little beyond the historical sketch provided by Schmitt himself, and does not explicitly compare the authors in the title. See Dirk Blasius, 'Carl Schmitt und Carl von Clausewitz: Vom Preußischen Volkskrieg zum tellurischen Partisanentum', Forschungen zur Brandenburgischen und Preußischen Geschichte, 24 (2014), 95-108.

${ }^{8}$ Beatrice Heuser, Reading Clausewitz (London, 2002), 48. This image also arises out of HansUlrich Wehler, ““Absoluter” und “totaler” Krieg: Von Clausewitz zu Ludendorff', [1969], in Clausewitz in Perspektive, ed. Günter Dill (Frankfurt am Main, 1980), 474-510; For contextual counterarguments that indicate the differences in Ludendorff's and Schmitt's readings, see Erik Grawert-May, Das Drama Krieg: Zur Moralisierung des Politischen (Tübingen, 1987), 285-328, particularly 295 and 309. 
For a more balanced view, we need to engage with Schmitt's theory of war more thoroughly than before. Herfried Münkler is one of the few who take into account Schmitt's theory of contained war, although without much chronological exegesis. Münkler identifies already in Clausewitz a combination of striving towards the moderation of war by balance of power, yet empirically perceiving tendencies towards escalation; this duality arguably enabled both Engels and Schmitt to lean upon Clausewitz - the former with escalation in mind, the latter with containment. ${ }^{9}$ This remark on the original tension is important for my reading, and the emphasis on Schmitt's containment argument remedies the imbalance left by most scholars' emphasis on intensification.

Exegetically implementing Münkler's points, I propose that Schmitt was both a theorist of statecentred politics and warfare and a thinker of the intensification of conflicts, and that both aspects were there from the outset. The two argument types are analytically separate, yet often intertwined. Sometimes Schmitt in containment arguments criticised others' regulating aspirations for actually intensifying wars; sometimes he proposed that political intensity culminating in war was a criterion of 'the political' - and 'political' containment thus partial at best. Unless we differentiate between different types of argumentation, we easily misconstrue Schmitt's reception of Clausewitz. Schmitt utilised Clausewitzian elements for both kinds of arguments, and I propose this very ambiguity is a Clausewitzian residue.

The argument is not one of Clausewitz's diffuse 'influence' on Schmitt, but rather concerns Schmitt's active reception of the Clausewitzian heritage that no German war theorists could escape. The aims, historical situations, and intellectual temperaments of the two writers were,

\footnotetext{
${ }^{9}$ Herfried Münkler, Über den Krieg: Stationen der Kriegsgeschichte im Spiegel ihrer theoretischen Reflexion (Weilerswist, 2008), 124-5, 127-8.
} 
obviously, quite different. ${ }^{10}$ Yet Schmitt found in Clausewitz's work elements that he considered useful for both systematic and historical arguments regarding the increased destructive potential of wars in modernity. These elements go beyond the famous rhetorical formulation of war as the continuation of politics, and Schmitt's relation to Clausewitz must not be reduced to a single phrase or extrapolated from it. Nevertheless, we must note that the dictum served as a crucial inlet for Schmitt into the whole question of the relationship between war and politics, and consequently I will make it one of the backbones of my analysis — not for the sake of convenience, but in order to be truthful to the way Schmitt actually read Clausewitz. The analysis seeks to dispel the apparent contradiction in Schmitt's readings that I opened the article with. Although playing opportunistic games with the words of the dictum, Schmitt had a clear grasp of the theoretical core behind it.

I will be arguing for six points in particular. First, although Schmitt once nominally rejected Clausewitz's continuity thesis, he remained faithful to the basic idea of the political nature of war, as becomes evident when analysing the functions that the rejection of the thesis served. Second,

${ }^{10}$ For an extensive analysis of Clausewitz's intellectual context, see Azar Gat, A History of Military Thought from the Enlightenment to the Cold War (Oxford, 2001), 158-265. A classic historical-biographical analysis is Peter Paret, Clausewitz and the State: The Man, His Theories, and His Times (Princeton, 2007[1976]). A recent biographical account stresses Clausewitz's battle experience. See Donald Stoker, Clausewitz: His Life and Work (Oxford, 2014). For analysis of individual battles such as Jena 1806, Moscow 1812, and Waterloo 1815, see Andreas HerbergRothe, Clausewitz's Puzzle: The Political Theory of War (Oxford, 2007), 15-38. The best intellectual biography on Schmitt is Reinhard Mehring, Carl Schmitt: A Biography, translated by Daniel Steuer (Cambridge, UK, 2014). For an accessible contextual introduction, see Gopal Balakrishnan, The Enemy: An Intellectual Portrait of Carl Schmitt (London, 2000). 
Schmitt did not seek to reverse the primacy of politics over the military, even in the era of total wars, and in particular he did not utilise the continuity thesis to this end; rather he gave political decision a permanent primacy. Third, Schmitt did not use the thesis to argue for the essential identity of war and politics: he saw politics as conceptually superior. Fourth, Schmitt neither sought to blur the war/peace distinction nor used the continuity thesis for such purposes, as several others did; rather the distinction was one of the conceptual axes of his work, although he also indirectly contributed to its blurring. Fifth, all of these points are somewhat eclipsed by Schmitt's oscillation between containment and intensification, but they become clear once we demarcate the argument types. The containment/intensification distinction is superior to the largely parallel dichotomy of existential/instrumental war in earlier scholarship. Sixth, in all of these points, I claim, Schmitt followed in Clausewitz's footsteps.

\section{Clausewitz's political theory of war}

Clausewitz was in many respects a child of his time. Combining Enlightenment tendencies for universalism with historicism derived from contemporaries like Müller, Savigny, and Schleiermacher as well as from his major military mentor Gerhard von Scharnhorst, Clausewitz was after a historically sensitive, yet universally valid theory of war; despite his historicist endeavours, Clausewitz, however, tended to treat the wars of his day as a timeless standard for wars in general. ${ }^{11}$ His personal experiences of Napoleon's wars are reflected in his abstract theorizing. He operated within a classical framework in which professional armies waged wars preceded by formal declarations, fought like duels and terminated by peace treaties; this he considered 'actual war'. ${ }^{12}$ Yet Clausewitz also analysed novel phenomena like people's war and

${ }^{11}$ Gat, History of Military Thought, 188 and 214; Paret, Clausewitz and the State, 71-73.

${ }^{12}$ Clausewitz, On War, 75, 603 (17, 672). 
partisanship, and in contrast to earlier approaches, such as the geometrical theory of Adam Heinrich Dietrich von Bülow which he openly challenged, he returned the focus on violent battle and underlined the cruelty of war. ${ }^{13}$ Clausewitz thus not only theorised on limited war as an instrument of policy, but also the forces that, with the French Revolution and the Napoleonic wars, rose to challenge this tradition. In perceiving both regulating and intensifying tendencies in war and in codifying distinctively modern vocabulary like 'tactics' and 'strategy', Clausewitz was arguably the first modern thinker of war.

Clausewitz's thought is heterogeneous, tension-ridden, and as a whole infamously obscure, not only due to his dialectical method, but also altering emphases and systematic rewriting. While his posthumous Vom Kriege provided the instrumental view, Clausewitz's 1812 Bekenntnisdenkschrift analysed popular uprising and the existential aspects of war. At the time, a war between France and Russia appeared inevitable, and for Clausewitz, Frederick William III's politics of neutrality and neglect of military preparation jeopardised Prussia's future autonomy. Having recently served at the Prussian General Staff under Scharnhorst and lectured in the War School in Berlin on small wars and guerrilla tactics, Clausewitz knew his terrain well. He rejected any alliance with France and called for an uncompromising defence of Prussia's 'existence' by popular uprising along the lines of the Spanish guerrilla war of some years earlier. ${ }^{14}$ His advocacy of a new way of war was thus intimately linked with a concern for national existence.

\footnotetext{
${ }^{13}$ On Bülow and Clausewitz, see Gat, History of Military Thought, 92-6.

${ }^{14}$ Carl von Clausewitz, 'Bekenntnisdenkschrift', [1812], in Schriften-Aufsätze-StudienBriefe: Dokumente aus dem Clausewitz-, Scharnhorst- und Gneisenau-Nachlaß sowie aus öffentlichen und privaten Sammlungen, ed. Werner Hahlweg (Göttingen, 1966), 678-750 (688, $721)$.
} 
Münkler identifies here an 'existential' view of war as a means for the nation to become conscious of its identity and goals—-something that transcends the habitual, manifests will, and is thus the highest form of politics, rather than its instrument. Whereas in the instrumental view the political subject remains unaltered, the 'existential' interpretation stresses war's potential to create historical situations and possibly new political identities. ${ }^{15}$ Here the political aspect clearly transcends the instrumental. However, while allowing that battles may sometimes revitalise the nation, even when $\operatorname{lost}^{16}$, Clausewitz did not generally urge peoples to seek their political destinies in war-in fact this horrified him. Instead of duel-like diplomatic wars, the wars of his era were 'wars of all against all' where peoples, not mere armies, confronted each other-something he hoped would not become the rule. ${ }^{17}$ Popular uprising was a pragmatic and exceptional means of defence in the face of the Napoleonic threat rather than a principle Clausewitz would have celebrated in its own right. We should thus refrain from overemphasising the existential aspect, yet also note that Clausewitz seriously engaged with questions of political existence in a particular historical context.

It is crucial to note that both the instrumental and the 'existential' view relied on the primacy of politics. Although Clausewitz theorised about partisan war and observed its originality and possible epochal significance, he did not assign it an independent position. Even the 'existential' aspects of Bekenntnisdenkschrift remained bound by the idea of the state. Clausewitz remained too much a thinker of his time to envision ideological partisanship outside this framework. In the altered political conditions of the new-born European concert, Clausewitz abandoned his youthful idealism and began to emphasize order, seeking primarily to secure the stability of the Prussian

\footnotetext{
${ }^{15}$ Münkler, Über den Krieg, 105-15.

${ }^{16}$ Clausewitz, 'Bekenntnisdenkschrift', 689

${ }^{17}$ Ibid., 749-50.
} 
state. ${ }^{18}$ The potentially disruptive phenomenon of popular uprising had to be harnessed both theoretically and pragmatically. In Vom Kriege, which Clausewitz wrote and rewrote gradually from 1816 onwards, he dealt briefly with popular uprising and noted with allusion to Napoleonic campaigns that Volkskrieg was 'an extension and amplification' of the 'fermentation process' of war. ${ }^{19}$ While seeing popular uprising as an anomaly, Clausewitz nevertheless considered it an extension of the standard framework and one form of defence, not anything independent.

The best way to tame the intensifying tendencies inherent in popular war was to contain war in its entirety by introducing a higher principle. Here idea of the political nature of war proved indispensable. To characterize war, the mature Clausewitz offered no less than three alternative models. He first defined war as 'an act of force' and 'the encounter of two living forces' ${ }^{20} \mathrm{He}$ sketched several immanent tendencies that intensify war and only then ventured to analyse realworld limitations, thereby qualifying his categories with empirical military history. Second, Clausewitz later differentiated between 'absolute' wars of decisive annihilation and limited wars fought for particular political objectives. Finally, he introduced the 'trinity' of initial violence, hatred and enmity (associated with the people); chance, probability, and free action (associated with the military); and war's status as a political instrument (associated with the government). ${ }^{21}$ For Clausewitz, war was 'absolutely not autonomous', but rather 'a political act'. ${ }^{22}$ It was senseless to 'subordinate the political viewpoint to the military' because politics 'generated the

\footnotetext{
${ }^{18}$ Paret, Clausewitz and the State, 421; Gat, History of Military Thought, 219.

${ }^{19}$ Clausewitz, On War, 479 (521).

${ }^{20}$ Ibid., 75, 77 (17, 20).

${ }^{21}$ Ibid., 89 (36-7).

${ }^{22}$ Ibid., 87, 605 (33, 674).
} 
war'. ${ }^{23}$ Politics was the 'womb' where war developed, and both carried traits of the other, just like the characteristics of living beings visible already in embryo. ${ }^{24}$ Further, the task of politics was to guide warfare until a peace treaty was signed: on its own, war could only explode like a waiting landmine. ${ }^{25}$ War was thus a political phenomenon whose particularity lay only in its means.

This context gave rise to Clausewitz' famous continuity thesis. The phrase itself is ambiguous and has been later invoked for various purposes often far removed from Clausewitz's; with respect to the general idea behind it, i.e. the proposition of the political nature of war, the nature of the continuity thesis, however, is relatively clear. While we may heuristically see the idea of acts of force as an energetic principle that gives war its impetus, the point of instrumentality provided a regulatory principle that limited these energies. Furthermore, while the definition of war in terms of original violence can be seen as an ontological statement regarding the nature of war, the continuity thesis's point, by contrast, was to make a relational claim regarding the roles, competences and proportions of war and politics within Clausewitz's conceptual system. Scholars disagree on whether the dictum is merely a description that registers factual relations and prepares war for systematic reflection or a prescription regarding war's effectiveness. ${ }^{26}$

No significant disagreement, however, prevails over the relational nature of the thesis, although the point is rarely made explicitly. Clausewitz's aim, reflected in the dictum, was not to

\footnotetext{
${ }^{23}$ Ibid., 607 (677).

${ }^{24}$ Ibid., 149 (113).

${ }^{25}$ Ibid., 87 (33).
}

${ }^{26}$ For an overview, see Christopher Daase and Sebastian Schindler, 'Clausewitz, Guerillakrieg und Terrorismus: Zur Aktualität einer missverstandenen Kriegstheorie'. Politische Vierteljahresschrift, 50 (2009), 701-31. 
characterise politics or war abstractly, but, first, to situate war within a hierarchy of concepts ${ }^{27}$ and, second, to give it coherence by subsuming its variations under one principle. ${ }^{28}$ Neither was the point of the continuity thesis to justify wars, although anyone reading Clausewitz's words on war as 'a genuine political instrument', after, say, the Kellogg-Briand Pact of 1928 which explicitly renounced 'war as an instrument of national policy' ${ }^{29}$, is liable to read a normative position into them. Clausewitz, however, sought to provide a conceptual framework for studying war, not to legitimise warfare. War's legitimacy as a political means was a premise of the classical framework, not a consequence of the continuity thesis in particular. The thesis had obvious normative colouring, too, but this was not its primary aspect.

Because of the original motivation, the thesis' reversal followed by no means naturally. This is crucial for our attempts to analytically differentiate between, first, Clausewitz's ideas of the relationship between politics and war, and, second, the phrase that has been taken to crystallise this idea but has also attained a somewhat confused life of its own. If we, incorrectly in my view, interpret the continuity thesis to say that politics and war are ontologically identical, then the reversed form ("politics is the continuation of war by other means") follows automatically. But Clausewitz's texts support neither step. He never spoke of politics as 'the continuation of war by other means', like many subsequent theorist have done ${ }^{30}$, and in fact this would have revolutionised his concepts. His point was also not to make ontological claims regarding politics

${ }^{27}$ Antulio J. Echevarria II, Clausewitz and Contemporary War (Oxford, 2007), 41.

${ }^{28}$ Cf. Herberg-Rothe, Clausewitz's Puzzle, 84.

${ }^{29}$ The Kellogg-Briand Pact, available online at http://avalon.law.yale.edu/20th century/kbpact.asp, accessed July 29, 2016. ${ }^{30}$ E.g. Michel Foucault, "The Society Must be Defended": Lectures at the Collège de France, 1975-76 (London, 2004), 16. 
or war, and particularly not to undermine the difference between the two, although objectives could often be achieved by either military or political means. Politics and war both had their designated places in Clausewitz's conceptual system, but being a military thinker rather than a political theorist in the ordinary sense, he was relatively uninterested in making claims about the nature of politics in any other role than as the guiding principle for his object of study, war. ${ }^{31} \mathrm{By}$ contrast, those eager to reverse the dictum on the rhetorical level usually aim primarily to say something about politics. They often also invoke the phrase in order to suggest that politics is in some sense war-like and to thereby question the peacefulness of 'peace'. ${ }^{32}$ This is equally distant from Clausewitz's original intentions: he did not purposefully blur the borderline between war and peace but rather underlined the violence of war precisely to demarcate it from peace, as pointed out by Aron. ${ }^{33}$

Furthermore, the perpetuation of wars or the reversal of competences in favour of the militaryfurther ideas often expressed with the inversion-are equally absent in Clausewitz. Admittedly he once noted that rather than being a 'despotic legislator', the political aim of war must sometimes adapt to military requirements, but otherwise Clausewitz consistently argued for the superiority of

${ }^{31}$ On the outline of Clausewitz's political theory, see Peter Paret, 'Clausewitz's Politics', in Understanding War: Essays on Clausewitz and the History of Military Power (Princeton, 1992), $167-77$.

${ }^{32}$ For instance Lenin invoked Clausewitz precisely in order to undermine the distinction between peace and war and also interpreted the dictum ontologically rather than relationally and therefore saw it as necessarily implying its reversal. See V.I. Lenin, “"Left-Wing” Communism: An Infantile Disorder', in Collected Works, Vol. 31: April-December 1920 (Moscow, 1966), 17-118 $(42,44,61,77,92-3$, and 102).

${ }^{33}$ Aron, Clausewitz, 62, 101-2. 
politics. ${ }^{34}$ The aim of warfare was 'a beneficial peace' or 'a peace treaty, which will solve the conflict' - not the 'preservation of one's own fighting forces' and 'the destruction of the enemy's' per se. ${ }^{35}$ It would be misleading to analyse military capabilities independently of this goal, to consider war an end in itself, or to pursue peace separately from the political process. While Clausewitz certainly shared Fichte's nationalistic sentiments and with most contemporaries - from Hegel to, somewhat more surprisingly, Kant - saw occasional wars as beneficial for national strength rather than something morally condemnable, we should not too easily read him as theorising politics as a form of warfare, as someone who preferred war over peace, or as a prophet of militarism. These are rather implications added in the subsequent tradition of interpretations. ${ }^{36}$ The fact that such ideas are often misleadingly attributed to the famous continuity thesis or its hypothetical reversed form, makes the thesis the focal point of the great Clausewitz quarrel. I here advance a moderate and cautious interpretation: in my view, the continuity thesis says what it literally says in its intellectual context, and little more. That context being late Clausewitz's instrumental theory of war, the idea of war as the continuation of politics and the concomitant phraseology link primarily to instrumental rather than existential considerations, and thereby to the attempt to regulate war.

This, however, is not quite the whole story—hence the italicized 'primarily' above. The instrumental doctrine offers Clausewitz's most elaborated views of war's political nature, but not all of it. Recent scholarship—emphasising the above trinity—has justly cautioned against

\footnotetext{
${ }^{34}$ Hans Rothfels, 'Clausewitz', in Makers of the Modern Strategy: Military Thought from

Machiavelli to Hitler, ed. Edward Mead Earle (Princeton, 1944), 93-113 (105).

${ }^{35}$ Clausewitz, On War, 471, 484 (510, 528-9).

${ }^{36}$ For an overview, see Heuser, Reading Clausewitz.
} 
identifying Clausewitz entirely with instrumentality. ${ }^{37}$ Primordial violence and unpredictability cannot be excluded, and the idea of the inevitably political nature of war is a more general concern than the narrow idea of war as an instrument of policy. An integrative interpretation of the 'existential' and instrumental aspects seems to me to be closest to the truth. Clausewitz noted popular uprisings with existential stakes, but perceived these as extensions of, and real-world deviations from, state-based war. In the instrumental view, too, war plans sprung 'from the political existence of both war-waging states' ${ }^{38}$ In highlighting the 'existential' elements in early Clausewitz, we should therefore refrain from accidentally portraying his instrumental view as a mere 'non-existential' theory of cabinet warfare, and therefore trivial or obsolete. Importantly, the continuity thesis lies a few lines above the passage just cited and thus evidently encompasses political considerations beyond instrumentality.

The trinity also sheds light on the double meaning of the political nature of war. Political motivations give rise to wars, and among these political causes are the concerns for existence as well as the enmity and hatred Clausewitz identified with the people. The more political the war, the more intense, closer to absolute war and, paradoxically, apparently more military it becomes. ${ }^{39}$ Yet it is also the task of political leaders — the third element of the trinity—-to guide warfare throughout, use war appropriately, and produce a politically acceptable peace. The reason why wars between civilised nations are less violent than others is found in these states' internal social conditions and mutual relations-elements that give rise to war, yet simultaneously 'determine,

${ }^{37}$ Herberg-Rothe, Clausewitz's Puzzle; Cf. Thomas Waldman, War, Clausewitz and the Trinity (Farnham, 2013).

${ }^{38}$ Carl von Clausewitz, 'Gedanken zur Abwehr', [1827], in Verstreute kleine Schriften, ed. Werner Hahlweg (Osnabrück, 1979), 493-527 (495).

${ }^{39}$ Clausewitz, On War, 88 (35). 
constrain [and] reduce' war. ${ }^{40}$ Politics is thus simultaneously both an impetus and a regulative principle: a cause of both intensification and containment.

This distinction, I propose, is analytically useful and superior to the parallel existential/instrumental duality employed in earlier scholarship. 'Existential' is an ambiguous term, as it may refer to (a) wars in which the existence of a nation is at stake, (b) wars that relate to the identity of the political community, or (c) wars in which warfare itself has 'existential' or metaphysical meaning for the community (in manifesting virtue, life force, etc.). Münkler's term encompasses both (a) and (b) and implicitly suggests (c). Schmitt, however, only used the term in senses (a) and (b), as will become evident. The ambiguity of the term 'existential' directly contributes to scholarship's overemphasis on intensification arguments, and I suggest the intensification/containment distinction captures the political nature of war better than the alternative dichotomy.

This peculiar duality is what gives Clausewitz's military theory its characteristically ambiguous flavour. It is, however, not simply that the theory is inarticulate or that the intensification/containment distinction merely adds to the series of internal tensions scholars have identified in Clausewitz. Although he never fully spelled out the implications, in analysing both intensifying factors and constraining forces Clausewitz arguably dealt with the key tension behind modern, that is post-1789, warfare in general - a tension that still resonates in the analyses of $20^{\text {th }}$ and $21^{\text {st }}$-century new wars, proxy wars and hybrid wars that are politically determined, yet increasingly difficult to regulate by policy. Clausewitz's substantial doctrines may have become obsolete, but the mode of analysis that accounts for both intensifying and containing tendencies

\footnotetext{
${ }^{40}$ Ibid., 76 (18).
} 
remains timely. ${ }^{41}$

In what follows, I propose that Carl Schmitt sensed this relevance amidst the early-20th-century ideological turmoil and therefore leaned on the Prussian general, albeit often merely by allusion. Certain reservations notwithstanding, Schmitt felt intellectual affinity with him, based, I claim, on nothing other than the intensification/containment perspective, which eventually also led him to praise Clausewitz's epochal significance. Let us, however, begin with the young Schmitt. Equipped with the working knowledge on Clausewitz summarised above, I will first show that Schmitt did not deviate completely from Clausewitz's theory in the Weimar Republic, although he apparently rejected the famous continuity dictum, abandoned the instrumental view and emphasised the intensification of enmity.

\section{Schmitt and Clausewitz in Weimar: Intensification and political containment}

Unlike Clausewitz, Schmitt never personally participated in war. During WW1, he served in an administrative position in Munich, showing no signs of national enthusiasm or belligerent tendencies and in fact fearing he would be recruited to the front. ${ }^{42}$ Writing mostly on political romanticism, Catholicism, parliamentary democracy, and legal theory, Schmitt did not comment on war directly in the immediate post-WWI context. However, war entered his repertoire

${ }^{41}$ On Clausewitz and new wars, see Herfried Münkler, The New Wars, translated by Patrick Camiller (Cambridge, UK, 2005), 32-4. For a call for new forms of 'containment' see Andreas Herberg-Rothe, 'Clausewitz and a New Containment: The Limitation of War and Violence', in Clausewitz in the 21 st Century, ed. Hew Strachan \& Andreas Herberg-Rothe (Oxford, 2007), 283307.

${ }^{42}$ Balakrishnan, Enemy, 16; Mehring, Carl Schmitt, 63. 
forcefully in two essays on the Rhineland crisis in 1925- as a reflection of the personal and political trauma of a lost war and foreign occupation of Schmitt's area of origin. ${ }^{43}$ Schmitt raged that the French occupiers oppressed Germany by bellicose measures that they legitimised as necessary to maintain peace while simultaneously rejecting any German attempt to revitalise the region as potential military mobilisation. In such conditions, Schmitt argued, peace and war became indistinguishable. ${ }^{44}$ These essays overlapped with Schmitt's criticism of the League of Nations as an attempt to legitimise the political status quo with legal concepts and 'the continuation of the old methods of war under a new name'. ${ }^{45}$ The Rhineland and League essays also contributed to Schmitt's theory of the political as relying on the distinction between friend and enemy, introduced in 1927 and revised in 1932 and 1933, but deriving from Schmitt's 192526 seminars.

During the Weimar period, Schmitt, then, altered between the three interrelated critiques, first, against the French occupation of Rhineland sanctified by the Versailles treaty, second, against the League of Nations' US-led imperialism masked as universalism, and, third, against the feeble Weimar liberalism that submitted to the limitation of its sovereignty and ius belli. In the Anglophone political theory, The Concept of the Political has been read mostly as an analysis of liberal parliamentary politics, but when linked to it historical and textual contexts, it appears rather as a treatise on war and international relations. This is the locus of Schmitt's only explicit

\footnotetext{
${ }^{43}$ For the context, see Balakrishnan, Enemy, 77-86.

${ }^{44}$ Carl Schmitt, 'Die Rheinland als Objekt internationaler Politik', [1925], in Frieden oder Pazifismus?: Arbeiten zum Völkerrecht und zur internationalen Politik 1924-1978 (hereafter FP), ed. Günter Maschke (Berlin, 2005), 26-50 (33-5); Carl Schmitt, 'Der Status quo und der Friede', [1925], in $F P, 51-72(52,59)$.

${ }^{45}$ Carl Schmitt, 'Die Kernfrage des Völkerbundes', [1926], in FP, 73-193 (88).
} 
comments on Clausewitz in Weimar and his first remarks on the relationship between politics and war. Schmitt's engagement with the questions of war, however, predates this famous text, as the Rhineland essays suggest.

Schmitt famously made the eventual possibility of physical battle and war the criterion of the political, thus forging a close conceptual link between war and politics: war was 'armed battle between organised political unities' and 'only the ultimate realisation of enmity'. ${ }^{46}$ In this context Schmitt made his first explicit remark on Clausewitz's continuity thesis - he rejected the idea. The note itself is ambiguous, and the fact that its function is often overlooked leads to confusion. Given Schmitt's struggle with the Clausewitzian heritage until the 1960s, it seems that his intention was something other than a simple rejection of Clausewitz altogether. I will analyse the revisions and changing argumentative contexts of Schmitt's remark and thereby excavate what I take to be his point.

In 1927, Schmitt wrote: "War is not "the continuation of politics by other means" as the famous definition is mostly cited; [war] is naturally not the aim and purpose of politics either, but the presupposition (that is always present as a genuine possibility) that determines human action in a characteristic way and gives it a specific political meaning. ${ }^{47}$ Schmitt's apparent rejection of the continuity thesis was perplexing, as he immediately afterwards stated—in accord with

${ }^{46}$ Schmitt, 'Begriff,' 4, 6. I will not here engage with the well-known general theory and its intricacies, but only focus on the aspects directly relevant to this article's argument. For nuanced interpretations and contextualisations, see the essays in Carl Schmitt: Der Begriff des Politischen: Ein kooperativer Kommentar, ed. Reinhard Mehring (Berlin, 2003) $\square$ and Freund-Feind-Denken: Carl Schmitts Kategorie des Politischen, ed. Rüdiger Voigt (Stuttgart, 2011).

${ }^{47}$ Schmitt, 'Begriff,' 8. 
Clausewitz-that war was not the purpose of politics. In Clausewitz's theory, too, military confrontation followed from the anterior political process, and war was waged in close interaction with the 'intellect' of policy: to state that war was the purpose of politics would spell a conceptual breach. There is thus a tension between the rejection of the dictum and the rest of the remark.

I argue that, despite his seeming rejection of Clausewitz, Schmitt saw war as a political instrument of state warfare in the cited passage. This is partly hidden, because in the better-known 1932 edition Schmitt augmented and reordered several sentences, the one invoking Clausewitz included. In 1927, the note on the continuity thesis was preceded by this sentence: 'War as the most extreme political means manifests the possibility of the distinction between friend and enemy that lies in the background of every political image, and [war] is therefore meaningful [sinnvoll] only insofar as this distinction in reality exists in humanity or is at least realistically possible. ${ }^{48}$ Two points are important here. First, Schmitt stated explicitly, albeit only in passing, that war was a political means. Second, he noted that only opposition between friend and enemy provided the idea of war with its sense. Immediately after this condensed remark follows the sentence where the continuity thesis was rejected. After that, with a reference to the sentence just analysed, Schmitt noted that the idea of war on purely religious, moral or economic grounds, without any sort of political element, was 'nonsensical' (sinnwidrig). ${ }^{49}$ This was so because, first, a friend/enemy grouping could not be derived from oppositions in the spheres of religion, morals or the economy, and, second, because as soon as these oppositions lead to war, a political grouping already exists. The rejection of the continuity thesis lies between the two other sentences and is a qualification of the general idea of the passage that the notion of war is meaningful only insofar as it contains a political element. This, again, is fully in harmony with Clausewitz's views.

\footnotetext{
${ }^{48}$ Ibid., 8.

${ }^{49}$ Ibid., 8-9.
} 
In an accompanying footnote on Clausewitz's view of war as 'a mere instrument of politics' Schmitt notes that 'war is that too', but that the meaning of war 'for the comprehension of the nature of politics is not thereby exhausted' ${ }^{50}$ What in Schmitt's mind went beyond the narrow instrumental interpretation pertained to war being an extreme case. Schmitt noted that particularly political tensions in human life derive from the 'most extreme possibility' of war. ${ }^{51}$ Consciousness of the eventuality of war makes war timely also in normal periods. In making this point, however, Schmitt did not reject the view of war as an instrument of policy per se, even if he verbally rejected the dictum; he only made a further theoretical point that went beyond the instrumental view that Schmitt attributed to Clausewitz. Schmitt here interpreted the dictum narrowly as a point regarding war's instrumental nature along the lines of cabinet warfare, thus underlining his deviation from Clausewitz to reinforce his own point of the potential intensification of wars. However, as shown above, Clausewitz's political view included the non-instrumental elements of enmity and violence, and Schmitt's note thus appears as largely unnecessary and misleading as a characterisation of Clausewitz.

Given this anti-instrumental intention, it would be erroneous to reduce Schmitt's reflections on the relationship between war and politics merely to the view of war as an instrument of politics; his most original contributions here instead relate to what goes beyond this view. However, the elaborations on the friend/enemy thesis should not overshadow the presence of the more traditional argument either. For Schmitt, war was a political means, even though it had other aspects, too. In the first sentence of his essay, Schmitt noted how the political had largely escaped the framework of the state and gained conceptual primacy; yet this shift was only underway still,

${ }^{50}$ Ibid., 8 note 4.

${ }^{51}$ Ibid., 7. 
and forms of state-based war remained in sight, as manifested in Schmitt's call for a traditional concept of war. The tension between containment and intensification is what gave Schmitt's essay its internal dynamics and topicality.

Between 1927 and 1932, Schmitt famously revised his theory: first, he extended his theory to domestic enemies and civil war, and, second, switched from 'the political' as a separate sphere to 'the political' as the highest degree of intensity of the friend/enemy distinction. ${ }^{52}$ The higher the intensity, the more 'political' the setting, Schmitt reasoned: war as the extreme manifestation of enmity was a political phenomenon par excellence. These changes were prepared in several essays commenting on intensification in both domestic and international politics. Schmitt identified a transition in which the traditional state/society constellation was replaced by society organising itself into a state. In this transition from absolute state via liberal state to 'total' state, everything was politicised in the specific sense of spreading potential sources of political demarcation into any arena and eventually bringing the weak Weimar state to the brink of civil war. ${ }^{53}$

While blaming the totalising tendency in domestic politics on liberal constitutional ideas and celebrating the early modern state's ability to terminate normative quarrels leading to civil wars, Schmitt simultaneously intensified his attack on contemporary Völkerrecht and the League of Nations. The world, he observed, was divided into friends and enemies in a state of nature, where nothing less than 'the political existence of the German people' was at stake. He called for the ${ }^{52}$ Heinrich Meier, Carl Schmitt \& Leo Strauss: The Hidden Dialogue, translated by J. Harvey Lomax (Chicago, 1995), 17-29.

${ }^{53}$ Carl Schmitt, 'Staatsethik und pluralistischer Staat', [1930] in Positionen und Begriffe im Kampf mit Weimar_Genf_-Versailles 1923-1939 (hereafter PB) (Berlin, 1988[1940]), 133-43 (141); Carl Schmitt, 'Die Wendung zum totalen Staat', [1931], in PB, 146-57. 
recognition of Germany's 'free, autonomous, unified and undivided existence' and its ability to decide by itself on 'existential questions', in particular whether it has been attacked, and on its right of self-defence'. ${ }^{54}$ The model here was the early modern state with its indisputable ius belli, which stood in stark contrast to the ban on war in the Kellogg-Briand Pact—a document that in Schmitt's estimation blurred the clear concept of war by not criminalising war per se but only national-political wars, while simultaneously allowing for 'operations' and 'occupations' as long as they were not openly called war. ${ }^{55}$ Here Schmitt generalised the argument of the Rhineland essays and introduced a point made more forcefully later: that the liberal attempt to limit war as a political means could not escape the problem of demarcating just and unjust wars, wherein lay the true source of the ideologisation and totalisation of warfare.

Schmitt thus perceived both domestic and international tendencies towards intensification and blamed both on liberalism and Western imperialism. The intensity model of the political codified these theoretically, amounting to an intensification argument. Both domestically and internationally, the historical counter-model was the classical state of the European balance of power. The truly 'existential' question of deciding on the identity of the political community occupied Schmitt at the time, and, criticising the blurred concept of war, he also called for a clear demarcation between war and peace as categories of international politics. ${ }^{56}$

${ }^{54}$ Carl Schmitt, 'Völkerrechtliche Probleme der Rheingebiet', [1928], in FP, 255-73 (264-5); Carl Schmitt, 'Die Politische Lage der entmilitarisierten Rheinlande', [1930], in FP, 274-80 (275).

${ }^{55}$ Carl Schmitt, 'USA und die völkerrechtlichen Formen des modernen Imperialismus', [1932/1933], in FP, 349-77 (362-4).

${ }^{56}$ See Timo Pankakoski, "Carl Schmitt Versus the "Intermediate State”: International and Domestic Variants', History of European Ideas, 39 (2013), 241-66. 
It is with these considerations in mind that we must approach Schmitt's use of Clausewitz in the 1932 edition of Begriff. Schmitt had now edited and supplemented the remark (changes are italicised).

Military battle, when contemplated in itself, is not the 'continuation of politics by other means', as the famous phrase by Clausewitz is mostly incorrectly cited, but instead has, as war, its own, strategic, tactical, and other rules and viewpoints that, however, simultaneously presuppose that the political decision on who the enemy is has already been made. ... War is definitely not the aim and purpose or the content of politics, but war is the presupposition (that is always present as a genuine possibility) that determines human action and thought in a characteristic way and thereby generates specifically political behaviour. ${ }^{57}$

Let us make three observations. First, Schmitt underlined that he analysed actual military battle (in contradistinction to 'war' in a metaphorical sense) and contemplated this 'in itself' and 'as war'. In this restricted sense, war had its own viewpoints. Again, this is in accord with how Clausewitz saw war as 'merely another kind of writing and language' with 'its own grammar'. ${ }^{58}$ Both stressed the military aspect's relative autonomy, yet noted its limits. While Clausewitz stressed that war did not have 'its own logic' but had to inherit this from the policy that caused the war, Schmitt similarly underscored that the particularities of war presupposed an antecedent political decision regarding the enemy. That none other than the Prussian general is the source of inspiration here is evident in the footnote where Schmitt translated Clausewitz's point to his own language, stating that war must inherit its logic "from the concepts of friend and enemy" and that this indeed is "the core of

${ }^{57}$ Carl Schmitt, The Concept of the Political: Expanded Edition, translated by George Schwab (Chicago, 2007[1932]), 33-4; Carl Schmitt, Der Begriff des Politischen (Berlin, 2002[1932]), 345.

${ }^{58}$ Clausewitz, On War, 605 (675). 
all things political."59

Second, Schmitt's point in the passage quoted at length was to maintain that concrete acts of war did not automatically follow from diffuse enmity. He stressed the discontinuity between politics and warfare in order to underscore that a sovereign decision was a fundamental guideline for military activity—not by any means to dissociate military activity from political regulation. Rather than to emphasise the autonomy of the military element, the point was-in harmony with the central thesis of the work-to accentuate the pervasiveness of the political, although Schmitt expressed this indirectly. On the same page he further underlined the sovereign decision's political rather than military nature: enemies in war 'usually confront each other openly as [enemies]' in uniforms, and 'the distinction between friend and enemy is therefore no longer a political problem that the soldier engaged in combat would have to solve'. ${ }^{60}$ The truly political problem of recognising enemies disappeared with the outbreak of war: regular land war between armies of sovereign nations was the primary reference point, although the expressions 'usually' and 'normally' left the door open for warfare by partisans without uniforms.

Third, and most crucially, the remarks on Clausewitz had also moved up several paragraphs towards the beginning, and the argumentative context was now different. In 1927, the apparent rejection of Clausewitz's dictum was linked with Schmitt's effort to show that war for war's sake and without a political component was an absurdity. In the 1932 passage, by contrast, Schmitt aimed to show that despite the contiguity between political and military spheres, his theory did not imply that all politics, even in the friend/enemy constellation, would lead to physical confrontation. In the latter formulation, the invocation of Clausewitz was immediately preceded by

${ }^{59}$ Schmitt, Concept 34n14 (34n10).

${ }^{60}$ Schmitt, Concept, 34 (34). 
Schmitt's apologetic note that his definition of the political was neither belligerent nor militaristic. ${ }^{61}$ While the 1927 argument suggested the ubiquity of the political, the 1932 argument was thus restrictive in nature, suggesting that war must be a mere 'potentially present presupposition' rather than an actuality. The rejection of the continuity thesis was now part of a caveat whereby Schmitt attempted to detach his theory from views that accentuated the military element.

In Schmitt's immediate historical and social context, such arguments were made by other radical conservatives who argued that war was to be granted interpretative, if not normative, primacy over politics - and reversed the Clausewitzian dictum to this end. ${ }^{62}$ Despite rhetorical affinities, Schmitt deviated from his conservative peer-group as regards the underlying assumptions of his state theory. ${ }^{63}$ Schmitt clearly acknowledged this, although it became explicit only in the 1933 edition, where Schmitt differentiated between the 'agonal' and the 'political' view of war. Here Schmitt referred to a discussion where Jünger advocated the former view, maintaining that 'man [was] not oriented towards peace', while Paul Adams underlined how war found its meaning in bringing about authority, order, and peace. ${ }^{64}$ Schmitt himself favoured the 'political' view. The role of political decisions was to provide war with meaning. Rather than peace in the abstract sense, the goal of such war was a political peace backed up by sufficient force on all sides so that a classic

${ }^{61}$ Ibid., 33 (33).

${ }^{62}$ Ernst Jünger, Der Kampf als inneres Erlebnis (Berlin, 1922); Ernst Jünger, Politische Publizistik: 1919 bis 1933, ed. Sven Olaf Berggötz (Stuttgart, 2001), 64; Hans Freyer, Der Staat (Leipzig, 1925), 142, 149; Oswald Spengler, Jahre der Entscheidung (München, 1933), 24.

${ }^{63}$ Scholars have noted these differences in passing. See, for instance, Meier, Carl Schmitt, 72-5; Meuter, 'Lob der Feindschaft', 395.

${ }^{64}$ Carl Schmitt, Der Begriff des Politischen (Hamburg, 1933), 10n1. 
power constellation would emerge. Sometimes this might entail destroying the political enemy, but even if one enemy were completely eradicated, order was needed to control the relations with other enemies.

We may disagree with the presumptions of this theory or criticise Schmitt's ability to follow it through, but unless we note the argumentative logic and its deviation from agonistic theories, we are prone to misconstrue Schmitt's position in relation to Clausewitz. This position cannot be deducted merely from Schmitt's denial of the dictum. First, there is much more to Clausewitz than a single rhetorical formulation, and second, the rejection can serve many purposes. I believe that Schmitt in 1932 had not abandoned the point that he argued in 1927 for by rejecting the dictum (war must have a political dimension in order to be meaningful), but he also made the restrictive argument that relations between states could be political in the emphatic sense even if wars did not actualise.

In arguing for the political nature of war, the primacy of the political decision on war, and the political nature of the peace that terminated war, Schmitt did not significantly deviate from Clausewitz's positions, although he rejected Clausewitz's dictum for the purposes of an intensification argument. Martin Tielke is thus partly right in spelling out the difference between Jünger and the 'non-militaristic' Schmitt in terms of the former's 'existential' view and the latter's purpose-oriented view along Clausewitzian lines. ${ }^{65}$ However, such a formulation risks erroneously reducing Schmitt's encounter with Clausewitz in the Weimar period to a theory of neat cabinet wars. Clausewitz's point about the political nature of war is a wider consideration, and the existential element of war must also be taken into account in Schmitt's reception, as scholars have

${ }^{65}$ Martin Tielke, Der Stille Bürgerkrieg: Ernst Jünger und Carl Schmitt im Dritten Reich (Berlin, 2007), 10. 
duly emphasised. James Dodd, for instance, explicitly denies that for Schmitt war could have any other sense 'than its existential sense' and notes that 'Schmitt's essay represents an important contribution to an existential conception of war' and 'stands out as a sophisticated and consistent rejection of the Clausewitzean option of emphasising its political instrumentality' ${ }^{66}$

The points by Tielke and Dodd seem to clash, but I believe both contain grains of truth; the scholars are focusing on different sides of the tension between 'instrumental' and 'existential' war. Three observations are relevant here. First, Dodd apparently uses the ambiguous term 'existential' to underscore that war manifests the existential decision by the political community and hence its identity—sense (b) above. While it is true, thus formulated, that war for Schmitt could not have any other sense than the existential, it is, however, crucial to note that Schmitt never stated that warfare itself - that is, the actual realisation of enmity in concrete military battle-would have an existential meaning, as Jünger, amongst others, underlined. Schmitt only stressed that the possibility, rather than actuality, of war had existential significance and that the political decision was existential. He theorised 'existential' politics, not 'existential' war in sense (c).

Second, Dodd overstates Schmitt's deviation from Clausewitz and leaves the average reader with the impression that Clausewitz had a thoroughly 'instrumental' view while Schmitt's was purely 'existential'. However, as shown earlier, Clausewitz's political theory of war went beyond the instrumentality of cabinet wars, and the thesis of continuity between politics and war was linked precisely to these wider considerations. Thus, the 'existential' aspects in Schmitt do not per se spell a deviation from Clausewitz, but at the most an alternative emphasis.

Third, in his Rhineland and League essays in the mid-1920s, Schmitt lamented the fact that the

${ }^{66}$ Dodd, Violence and Phenomenology, 38-9. 
categories of war and peace of traditional Völkerrecht were utilised for partisan ends and that the prospects for traditional and non-ideological wars were thus diminished. His theory of the political, with its stress on the intensification of enmity to the point of war, was a theoretical codification of this observed symptom, not a political prescription, and the elaboration of the friend/enemy distinction by no means implied a rejection of the traditional framework altogether. While Schmitt rejected Clausewitz's dictum and went beyond the merely instrumental view of political war that he partly erroneously attributed to Clausewitz, he did not abandon Clausewitz's political theory of war in its entirety. Rather than being a 'consistent rejection' of Clausewitz's instrumental view, Schmitt's theory thus appears as a tension-ridden compound, comprising element of both intensification and containment.

Admittedly, the intensification arguments loom large in the text. Already in the opening lines of The Concept of the Political Schmitt denied that the state any longer had a monopoly of the political and therefore, with implicit reference to Georg Jellinek's traditional state theory, reversed the primacy of the state in favour of the now autonomous "political" ${ }^{67}$ Parallelly, Schmitt's point about war in the treatise was that wars too had escaped the traditional confines of the nation states and that the autonomous principle of the political now manifested in both interstate wars and civil wars. These arguments of autonomy and intensification echoed those by Clausewitz who observed that political enmity intensified wars, that it would be an absurdity to build 'a principle of moderation' into war theory itself, and that the outside force of politics was therefore needed. ${ }^{68}$ Schmitt similarly postulated an autonomous intensifying force, which he relabelled as 'the

${ }^{67}$ See Christoph Schönberger, 'Staatlich und Politisch: Der Begriff des Staates in Carl Schmitts Begriff des Politischen', in Carl Schmitt: Der Begriff des Politischen: Ein kooperativer Kommentar, ed. Reinhard Mehring (Berlin, 2003), 21-44 (21). ${ }^{68}$ Clausewitz, On War, 76 (18). 
political', that was exclusively a principle of intensification and, given Schmitt's definition of the political as the highest degree on the scale of intensity, logically could not include any moderating elements. Containment had to be brought from the outside, and the primary containing force was nothing other than the traditional state. The intensification Schmitt observed did not mean that the transition beyond the state was complete and fulfilled, and neither was war completely detached from state regulation. The work moved on two parallel tracks, both dissociating the political from the state and re-associating the two, as noted by Christoph Schönberger. ${ }^{69}$ The challenge of the political to the traditional state framework was at the very least isomorphic with the challenge posed by enmity-based popular war on the framework of traditional interstate warfare, analysed by Clausewitz some hundred years earlier.

The import of my reading so far is to show that the intensification/containment tension prevailed already in the Weimar period. At this point, Schmitt theorised the transformations of war by underlining the element of ideological intensification as well as identified the culprits for the miserable condition (the French, the Allies, the Americans, the League of Nations, and Weimar liberals), but he did not yet spell the historical aetiology of the disease or suggest the remedy. For these arguments, we have to turn to his post-1939 work. Let us, however, first follow Schmitt's engagement with Clausewitz and war in the Third Reich.

\section{Schmitt and Clausewitz in the Third Reich: Competences, Containment and Unbound Intensity}

Schmitt not only supported the Prussian coup in 1932, but as the 'Crown Jurist' of the Third Reich, also opportunistically legitimised the Röhm Putsch in 1934, contributed to academic 'co-

${ }^{69}$ Schönberger, 'Staatlich und Politisch', 24. 
ordination' by secluding Jewish scholars, and sought to bridge his theory with National-Socialistic vocabulary up until his breach with the party in $1936 .{ }^{70}$ At the period, his engagement with Clausewitz took three forms. First, he commented on the proper competences between politics and the military. Second, he rephrased the intensification/containment opposition in terms of 'enmity' and a 'political view of war'. Third, he commented on the question of the gradation of war and the peace/war dualism. I will analyse these themes in turn, because Clausewitz, I claim, lies at the background of each.

At the beginning of the Third Reich, Schmitt published the third edition of Begriff. The passages on Clausewitz remained largely unaltered, but Schmitt now further underlined that 'the politician, not the soldier', decided upon the enemy, ${ }^{71}$ thus restating the question of the relationship between politics and war as a question of competences. A clear parallel with Clausewitz can be perceived here. As Rothfels noted, the 'whole trend' in Clausewitz's thought points to the direction of the superiority of politics rather than 'the superiority and self-sufficiency of the military., ${ }^{72}$ In a 1934 study of the military in German constitutional history, Schmitt engaged directly with the role of the military in order to further underline political responsibility. He explained the defeat in WWI in terms of a nineteenth-century constitutional flaw that marginalised the army politically and splintered the political unity into military, economic, and political sectors. In Schmitt's view, any of these three elements should have the ability to make comprehensive claims and become truly political: 'The political is the total, and this totality can be enforced starting with the economic and

\footnotetext{
${ }^{70}$ For historical contextualisation, see Dirk Blasius, Carl Schmitt: Preußischer Staatsrat in Hitlers Reich (Göttingen, 2001).

${ }^{71}$ Schmitt, Begriff (1933), 17.

${ }^{72}$ Rothfels, 'Clausewitz', 105.
} 
financial side just as well and just as logically as starting with the military side. ${ }^{73}$ These points were in harmony with Schmitt's idea of the political as independent of any substantial domains: the military could become a political force just like any other. In the present context, in fact a political force had arisen in the form of 'the political soldier' Adolf Hitler ${ }^{74}$. When read in its context, these ideas link directly to the inner division between Hitler and the Reichswehr on one side and Röhm and SA on the other - Schmitt, after all, legitimized the Röhm putsch the same year. ${ }^{75}$ The argument was by no means unsympathetic towards the Prussian army, now apparently represented by the Reichswehr, as a guardian of traditional legal and administrative forms, on the one hand, and the army's position in decision making, on the other. Nevertheless, Schmitt did not argue for the military element's primacy per se, but rather claimed that the best way to prepare for war was to incorporate the military within the totality of the state, yet give primacy to the political element. Despite admiring the Prussian soldier tradition manifested by the Reichswehr, Schmitt did not seek to reverse the competences between the military and the political element in the Third Reich. The doctrine of the political primacy, as formulated in the context of his remark on Clausewitz's continuity thesis in 1933 , became instrumental for Schmitt's attempt to cement the Führer's position within the Reich.

However, the same argument also helped Schmitt to indirectly support Germany's right to wage war, as becomes evident particularly in two 1936 texts on total wars in the era of total politics. ${ }^{76}$ Two partly conflicting elements emerged in these essays: the first was, again, a rather traditional

${ }^{73}$ Carl Schmitt, Staatsgefüge und Zusammenbruch des zweiten Reiches: Der Sieg des Bürgers über den Soldaten (Hamburg, 1934), 29.

${ }^{74}$ Ibid., 49.

${ }^{75}$ See Blasius, Carl Schmitt, 119-51.

${ }^{76}$ Carl Schmitt, 'Die Ära der integralen Politik', [1936], in FP, 464-68; Schmitt, 'Politik'. 
containment argument on political war along Clausewitzian lines, while the second, an intensification argument, implied a transgression of that framework. I will deal with each in turn with the intention of showing, again, the interaction and tension —an essentially Clausewitzian tension-between them.

In the dictionary entry on 'Politik', Schmitt returned to the question of the meaning of war on the one hand and the Clausewitzian dictum on the other. The core difference in the rival notions of the political, Schmitt argued with reference to his 1933 statement, lies in the question of whether war carries 'meaning' in itself or only becomes meaningful through the subsequent peace. Schmitt again underlined his deviation from Jünger: in Jünger's belligerent view, 'man is not oriented towards peace', whereas in the political view war was meaningfully (sinnvollerweise) waged for the sake of peace and thus a 'means of politics'. Here Schmitt again invoked Clausewitz's authority and this time quite favourably: 'War is, as Clausewitz says in his book On War, a "mere instrument of politics" and "nothing other than a continuation of political interaction with the involvement of other means", 77

Had Schmitt, then, changed his mind vis-à-vis the statement in Begriff that war was not 'the continuation of politics with other means'? The two points appear to clash. Rather than a change of positions, I believe this was a new accentuation. Schmitt again cited the dictum to bolster his political view of war. Now he also underlined that although in the age of totality politics could not escape war completely, there could still be more noble causes for it than mere annihilation. The argument was one regarding the containment of war, whereas in Begriff Schmitt only explicitly commented upon the continuation thesis when developing an intensification argument. The affirmation of the continuity thesis for the purpose of advancing a containment argument in 1936

${ }^{77}$ Schmitt, 'Politik', 137. 
is fully compatible with the rhetorical rejection of the thesis for the sake of the intensification argument earlier. The discrepancies I opened the article with are genuine; yet when read in their argumentative and ideological contexts and interpreted through the containment/intensification prism, they become somewhat relativized. In the Weimar era, the political was an intense force predestined to escape and explode the feeble constitutional framework, while in the Third Reich an authoritarian leader, in Schmitt's view, had managed to harness the destructive forces, and this political act of strength he now cherished. In 1936, Schmitt utilised Clausewitz's authority and the continuity thesis ideologically, and he even portrayed Hitler as a representative of the peaceoriented 'political view' ${ }^{78}$ In Schmitt's estimation, war was for Hitler a means of politics and the aim of war was peace - a point not to be taken at its face value by anyone familiar with Schmitt's own formula that everyone wants peace but what matters is who concretely decides what counts as peace. Schmitt clearly defended the National Socialist regime's ius belli. Crucially, however, he did this not by reversing the Clausewitzian dictum like most contemporaries but precisely by maintaining its original formulation. Schmitt built the 'political' view upon Clausewitz's instrumental theory of war and on this basis resisted the 'agonal' or 'belligerent' positions of those who asserted the primacy of war. Schmitt's invocation of Clausewitz may have been rather shallow, and his contextual motivations highly ideological, but his use of the dictum was compatible with Clausewitz's intentions (while, for instance, Ludendorff's ${ }^{79}$ arguments for military primacy in the era of total wars were not).

While in 'Politics' essay, Schmitt invoked Clausewitz in the context of the political containment of peace, in the other 1936 essay Clausewitzian elements contributed to an intensification argument. Schmitt noted that 'politics' could no longer be equated with external relations because total war

\footnotetext{
${ }^{78}$ Ibid.

${ }^{79}$ Erich Ludendorff, Der Totale Krieg (München, 1935).
} 
had necessitated full internal unity to support the war effort and because the friend/enemy distinction now determined both internal and external politics. In Schmitt's view, no 'real enmity' to match the intensity of the war effort prevailed before WWI, and the 'total enmity' born in the war still remained. ${ }^{80}$ The epochal significance of the first truly total war was that it brought about changes in political structures. Here Schmitt went beyond Clausewitz, who perceived epochal changes in the nature of war but did not theorise on the influence of war on politics; instead Clausewitz only underlined how the nature of politics determined the nature of the ensuing waragain one meaning carried by the continuity thesis.

Despite the pseudo-Clausewitzian terms 'total enmity' and 'real enmity', ${ }^{81}$ somewhat surprisingly Schmitt did not utilise Clausewitz in analysing the interrelations between total politics and total war. This is all the more surprising given that he even labelled Clausewitz the first theorist of total war: 'In a certain sense there have always been total wars; a theory of total war, however, only exists since Clausewitz who spoke of "abstract" and "absolute" war., 82 Who would have been a better authority to rely on? The reason for this dismissal, I believe, becomes evident two pages later. Schmitt notes Clausewitz's efforts in theorising mass mobilisation and popular uprisings in land warfare, but points out that maritime war is essentially war against the enemy's economy and

${ }^{80}$ Schmitt, 'Die Ära integralen Politik', 465.

${ }^{81}$ Clausewitz (On War, 579 [642-3]) speaks of e.g. 'absolute and real war' and 'total discharge' of the belligerent potential but not of real or absolute enmity.

${ }^{82}$ Carl Schmitt, 'Totaler Feind, totaler Krieg, totaler Staat', [1937], in FP, 481-507 (481). The reference is as inaccurate as the previous one in conflating 'absolute' with 'total war'-for Clausewitz, the former was a purely theoretical concept, while the latter was genuinely possible. See, e.g., Echevarria, Clausewitz and Contemporary War, 40. 
thereby also against non-combatants and neutrals. ${ }^{83}$ For Schmitt, English maritime war was the true source of total war, and he considered Clausewitz's land-based categories obsolete.

'Enmity' rather than 'war' had become the central concept: total enmity was what gave meaning to total wars, and this in turn determined the nature of total states ${ }^{84}$ Schmitt ultimately sought to blame liberalism and the Allies for the totalisation of both warfare and politics. The Versailles Treaty had not brought genuine peace but rather intensified hostilities, and with the adoption of English maritime categories into Völkerrecht, war transcended traditional boundaries. The meaning of war no longer lay in peace, as stated in the 1936 containment argument, but rather in enmity set loose from bounds, as now observed in an intensification argument. The basic point about the political nature of war prevailed, however, as this total enmity was political in a particularly strong sense: Schmitt anticipated that Europe might again drift into war so that enmity only arose as a consequence of the total war instead of a 'previously existing, ineradicable, genuine and total enmity' leading to war, as was 'right and meaningful [sinnvoll]' ${ }^{85}$

Upholding the idea of war as a political rather than judicial phenomenon, Schmitt in 1938 resisted the criminalisation of war by the League, arguing that any normative regulation of war counterproductively led to its totalisation. In outlawing only some wars, a 'discriminating' concept of war shattered the classical framework of wars between sovereign states and made neutrality

\footnotetext{
${ }^{83}$ Schmitt, 'Totaler Feind', 483.

${ }^{84}$ Ibid., 482.

${ }^{85}$ Ibid., 485.
} 
impossible, Schmitt reasoned. ${ }^{86}$ Wars were now waged like before, but only framed as defensive wars and justified with moral criteria; the distinction between just and unjust wars thus intensified, rather than contained, war and enmity ${ }^{87}$ The attempt to limit the ius belli was thus, for Schmitt, the real cause of total wars. As wars became total, the distinctions of enemy/criminal, combatant/non-combatant, front/civilian territory and war/peace dissolved, and abnormal 'intermediate states' emerged. ${ }^{88}$ Schmitt's analysis of totality thus built upon his criticism of the intermediate state in the 1925 Rhineland essays and beyond.

There is an intimate link between the intermediate state argument and the inverted Clausewitzian dictum: politics conducted as if it were war undermined the classical categories. In a 1937 essay, Schmitt criticised the idea of pirates as 'enemies of the humankind', proposed in the diplomatic conference in Nyon, Switzerland. He again warned about 'intermediate concepts between open warfare and genuine peace' ${ }^{89}$ In a letter to Jünger, Schmitt explicated his anti-English antipathy: the essay emerged from Schmitt's angst over 'how cold-bloodedly the Anglo-Saxons continued the world war [in Nyon].${ }^{90}$ After this hint at the link between the intermediate state and the reversed continuity thesis, he made the point explicitly in 1938. Schmitt argued that non-military areas had been drawn into play, leading to 'economic war', 'propaganda war' and other equally ${ }^{86}$ Carl Schmitt, 'The Turn to the Discriminating Concept of War', in Writings on War, translated and edited by Timothy Nunan (Cambridge, UK, 2011) 30-74 (63-6); Carl Schmitt, Die Wendung zum diskriminierenden Kriegsbegriff, [1937-38], in FP, 518-97 (553-5).

${ }^{87}$ Ibid., 72 (562).

${ }^{88}$ Ibid., 32 (519-20).

${ }^{89}$ Carl Schmitt, 'Der Begriff der Piraterie', [1937], in PB, 240-3 (243).

${ }^{90}$ Schmitt to Jünger, November 14, 1937, in Ernst Jünger and Carl Schmitt, Briefe 1930-1983, ed. Helmuth Kiesel (Stuttgart, 1999), 69-70. 
aggressive forms of enmity. The distinctions between combatants/non-combatant and peace/war were thus lost in favour of 'an abnormal intermediate condition between war and peace'. The unsurprising culprits were again the Kellogg treaty, the League and the Versailles treaty, which 'wanted to turn peace into a "continuation of war by other means", yet sought to legalise this intermediate state by pacts. ${ }^{91}$

This is the only time that Schmitt utilised the inverted Clausewitzian formula for rhetorical purposes. We must note that Schmitt's remark is one regarding peace, not politics or war. Given his earlier observation that the dictum is cited 'incorrectly' when abbreviated into the form that war is the continuation of politics by other means, Schmitt was doubtless aware of the further incorrectness of substituting 'peace' for 'politics'. The inverted commas around the phrase suggest such reservations. Schmitt did not say anything like this in Begriff, and here too he used the inverted dictum pejoratively in his vehement diagnosis of the current crisis, not in constructing his own view of the political in abstracto. It is thus misleading to see Schmitt as being 'influenced by Clausewitz's dictum' that allegedly asserted both 'the political character of war' and 'the war-like character of politics', ${ }^{92}$ or to claim that Schmitt took as his starting point the 'statement that war is politics continued by other means and that naturally [...] politics is war continued by other means. ${ }^{93}$ These may be apt rhetorical descriptions of Schmitt's endeavours, but mostly they go

${ }^{91}$ Carl Schmitt, 'Über das Verhältnis der Begriffe Krieg und Feind', [1938], in FP, 598-611 (6012).

${ }^{92}$ Ernesto Laclau, 'On "Real” and "Absolute” Enemies', CR: The New Centennial Review, 5 (2005), 1-12 (6).

${ }^{93}$ José Rafael Hernández Arias, Donoso Cortés und Carl Schmitt: Eine Untersuchung über die staats- und rechtsphilosophische Bedeutung von Donoso Cortés im Werk Carl Schmitts (Paderborn, 1998), 94. 
against the grain of his actual argumentation in placing the original formulation and the inversion on the same conceptual level and presuming that one entails the other. The logic of Schmitt's argumentation is rather that the distinction between peace and war should be maintained even though blurred intermediate forms empirically occur.

This, I claim, is a particularly Clausewitzian approach, and we have good grounds to conclude that Schmitt here built on the Prussian general. Both authors posed questions regarding war and peace similarly: they started with non-gradated categories, yet perceived empirical gradations. For Clausewitz, war and peace were concepts 'that admit no gradations'; nevertheless, empirically the suspension of action often reduced war to a 'half-thing', and war could thus be 'now more, now less war' ${ }^{94}$ While observing degrees of confrontation and threads of peace in war, however, Clausewitz never questioned the demarcation between war and peace as two distinct conditions. The gradations were always within the category of war, not between war and peace, and he did not relativise peace.

In this respect, Schmitt felt obliged to surpass Clausewitz's perspective and to perceive gradations between war and peace empirically and critically in the post-WW1 context, albeit by no means implying that this should be so. In accord with Clausewitz's remark on war and peace admitting no gradations, Schmitt rather posited a clear war/peace distinction. On the level of critical observation, on the other hand, he identified factors that in reality blurred this dichotomy. This two-fold conceptual strategy fit with that of Clausewitz. Schmitt never cited Clausewitz's rejection of gradations or his observations on intermediate forms, but he evidently acknowledged Clausewitz's characteristic duality of the conceptual and empirical levels. There is some indirect textual evidence for this, too. In a footnote in Begriff, Schmitt invoked Clausewitz's passage on

${ }^{94}$ Clausewitz, On War, 216-8, 580-1, 603 (193-6, 644, 673). 
alliances as support for his thesis on the centrality of the friend/enemy opposition. ${ }^{95}$ Clausewitz's note on the concepts of war and peace admitting no gradations is on the very same page in $\mathrm{On}$ War, and it is highly improbable that Schmitt would have been unaware of it. For the third edition of Begriff, Schmitt omitted the reference (probably to make the name of his Jewish colleague Rothfels disappear) and replaced it by a mere note that 'war can, depending on the degree of enmity, be more or less war. ${ }^{96}$ This is effectively Clausewitz's empirical note on the existence of gradations, now paraphrased in the Schmittian language of enmity.

We can easily substitute 'intensity' for the degree of enmity, because this is how Schmitt defined his concept of the political in the early 1930s. The trouble now was that the liberal West had politicised traditional Völkerrecht and thereby unbound such intensities from the regular state framework, on the one hand, and extended enmity to periods of apparent peace, on the other. As enmity, which did not respect judicial categories, had become the key to modern total war, the Clausewitzian gradations now extended across the war/peace boundary. This was the detrimental condition Schmitt analysed by theorising intensification, and to this challenge he replied, first and shockingly, by framing Hitler's efforts as peaceful in the hope that the new regime would reestablish international order and, second, by developing important theoretical tools for the justification of the Reich's ius belli. I will deal with these shortly.

To conclude, from 1933 to 1939 , Schmitt, first, adhered to the view of war as a political phenomenon and reasserted the point as a matter of competences. Second, he stated with Clausewitz's authority that war found its meaning in peace (containment argument) and the next year stated pejoratively and with Clausewitzian terms that the framework of state war had been ${ }^{95}$ Schmitt, Begriff (1932), 34n10. This passage is unavailable in the English translation. ${ }^{96}$ Schmitt, Begriff (1933), 16 n7. 
surpassed and unbound enmity provided war with its meaning (intensification argument). Third, when theorising on intensification, he linked the inversion of the continuity thesis with the intermediate state argument in his criticism of turning war into a judicial rather than political matter.

\section{From Third Reich to post-war partisanship: Containment historicised}

From 1939 onwards, Schmitt engaged increasingly with the theme of space (Raum) in international law, and this when the origin of his post-war arguments on the 'Nomos' of the Earth also start accumulating. ${ }^{97}$ With this change into political geography and into the philosophy of the elements of land and sea, Schmitt sought to discover novel theoretical foundations for the international order. Schmitt continued criticising the weak Anglo-Saxon ideas of peace, on the one hand, and called for a space-based understanding of political order with the ostensible aim of securing lasting peace. This was a direct response to the Weimar problem of 'the political' escaping state boundaries - an attempt to rechannel the loose intensities into a structure.

Correspondingly, the oscillation between containment and intensification in Schmitt's argumentation continued in this era, and, I claim, this dual interpretative perspective is crucial for the correct comprehension of Schmitt's account of Clausewitz from roughly 1939 onwards up until the end of his career. The time span may be extensive in terms of the history of events, but with regard to the role of Clausewitz and political war within Schmitt's thought, this is a single era of coherent development.

${ }^{97}$ See, e.g., Peter Haggenmacher, 'Présentation: L'itinéraire internationaliste de Carl Schmitt,' in Carl Schmitt, Le nomos des la terre dans le droit des gens du jus publicum europaeum (Paris, 2001), 1-43, 12 . 
At the eve of war, Schmitt confronted the observed intensification with novel categories that, however, still built on the traditional framework of state war and maintained the Clausewitzian heritage. States were now to be understood as 'concrete orders', capable of 'radiating' their ideology on their 'large space' (Großraum).${ }^{98}$ The Großraum scheme, modelled after the Monroe doctrine, excluded any intervention from outside, and it its historical context, the theory was directed particularly toward US or Soviet intervention with the German expansion efforts. Despite Schmitt's breach with the Nazi regime around 1936, a German-led European 'large space' nevertheless lay in the horizon for him and this was what his new categories in practice came to support. More theoretically, his new theory sought to defend a properly German way of understanding political war. Each concrete order, Schmitt claimed, also produced its own notions of war and peace: the 'continental war of combatants' where sovereign states decided upon war now clashed with the Anglo-Saxon view that instead linked war with judicial norms and also included reprisals or blockades. ${ }^{99}$ For Schmitt, however, the inalienable ius belli was as fundamental as the right to decide upon friend and enemy, and both rights remained also in the era of total wars. ${ }^{100}$ Schmitt stretched his idea of political unity from the national to the Großraum level, yet retained the basic principle of the political nature of war.

Wars were certainly not mere instruments in cabinet politics, as they manifested uttermost oppositions between concrete orders that divided the world. Yet it was precisely this that provided

${ }^{98}$ Carl Schmitt, Völkerrechtliche Großraumordnung mit Interventionsverbot für raumfremde Mächte: Ein Beitrag zum Reichsbegriff im Völkerrecht, [1939/1941], in SGN, 269-371 (270, 296). ${ }^{99}$ Carl Schmitt 'Raum und Großraum im Völkerrecht', [1940], in SGN, 234-68 (250); Carl Schmitt, "Auflösung der europäischen Ordnung im "International Law", [1940], in SGN, 372-87 $(378,381-2)$.

${ }^{100}$ Schmitt, 'Auflösung', 382. 
wars with political meaning. The autonomy of the political decision still carried potential for intensification, but Schmitt also retained two elements that instead contributed to containment: on the one hand, Schmitt saw wars as 'duels' between equally sovereign concrete orders; on the other, he theorised spatial segregation along 'amity lines' dividing the world since the sixteenth century in order to rob European confrontations of their severity. ${ }^{101}$ Accordingly, the contemporary total 'battle for existence' was to be terminated by a 'total peace' and a 'peace based on an order of space'. ${ }^{102}$

The idea of Großraum as peace is disquieting, of course, but structurally the argumentation remained compatible with Clausewitz's political theory of war in its emphasis on the demarcation between war and peace rather than their interpenetration. Schmitt repeated that 'the meaning of every non-meaningless war lies in the peace that ends the war' ${ }^{103}$ — that is, the point he had in 1933 called the 'political view' and in 1936 supplemented with the Clausewitzian dictum. The statement again contradicted the 1938 point that enmity provided this meaning, but instead of being a substantial change of positions, this difference rather only reflected the oscillation between intensification and containment. In the Großraum scheme, the statements were in fact compatible: enmity gave rise to political orders that waged wars both within their separate territories and with each other until peace was attained, and then withdrew.

The arguments of The Nomos of the Earth (1950), Schmitt's post-war magnum opus written during the war, arose directly out of these considerations. The volume celebrated the early-modern

${ }^{101}$ Schmitt, Völkerrechtliche Großraumordnung, 301, 313.

${ }^{102}$ Carl Schmitt, 'Die Raumrevolution: Durch den totalen Krieg zu einem totalen Frieden', [1940], in SGN, 388-94 (389-90).

${ }^{103}$ Ibid., 389. 
'bracketing' (Hegung) of war ${ }^{104}$, and correspondingly it has been read as providing the mature Schmitt's realistic, yet moderate theory of international order and war. Certainly, the emphasis in the volume is on the containment of war, which now had two components: first, the neutralisation of confessional conflicts by the early modern state and the replacement of the mediaeval just war doctrine by duel-like interstate wars based on equal sovereignty, and, second, spatial demarcations and borderlines beyond which wars were allowed and European tensions thus 'discharged' ${ }^{105}$ Nominally, this was a historical defence of the ius publicum, but the overlap with Schmitt's prewar writings is too extensive to allow for a purely historical reading. In the post-war context, Schmitt had ideological reasons to downplay his active Großraum project in favour of mythological-historical analysis and to represent his theory of the political as responding to the problematic intermediate state after the collapse of the traditional framework rather than as contributing to this tendency. ${ }^{106}$ This apologetic strategy, I claim, was possible because Schmitt's work since the Weimar period contained elements of both intensification and containment to begin with, as shown above. In The Nomos of the Earth, Schmitt engaged with Clausewitz only implicitly; yet Clausewitz played a key role in the historical narrative that Schmitt provided to bolster his arguments. Recapitulating the historical narrative is thus not only crucial for understanding how the Nomos book arose out of earlier considerations, but this analysis also ${ }^{104}$ Carl Schmitt, The Nomos of the Earth in the International Law of the Jus Publicum Europaeum, translated by G. L. Ulmen (New York, 2003), 187; Carl Schmitt, Der Nomos der Erde im Völkerrecht des Jus Publicum Europaeum (Cologne, 1950), 158.

${ }^{105}$ Schmitt, Nomos, 90-100, 120-1, 140-7, 187 (59-69, 91, 112-9, 158-9).

${ }^{106}$ Carl Schmitt, 'Vorwort', [1963], in Schmitt, Begriff (1932), 9-19 (13-15). The introduction is not included in the English translation. For criticism of Schmitt's attempt to re-contextualise his book, see Hasso Hofmann, 'Feindschaft - Grundbegriff des Politischen?', Zeitschrift für Politik, 12 (1965), 17-39. 
makes comprehensible Schmitt's highly ambiguous remarks on Clausewitz up to the 1960s.

During the war, Schmitt started to 'historicise' the tension between the continental and AngloSaxon frameworks. The centralised state, Schmitt argued, emerged as a neutralising force after the sixteenth-century confessional civil wars and turned private feuds into 'state war'. This model of 'pure land war' brought about a rationalisation of war and made it a legal matter, as civilians and private property were spared, but a shift from land to sea in Elizabethan England broke the European unity. ${ }^{107}$ A contemporary manifestation of this historical shift was maritime war, which in Schmitt's view was based on a total concept of the enemy: in the economic war of blockades, all citizens of the enemy nation and anyone who traded with them were considered enemies. ${ }^{108}$ These arguments were intimately linked with Schmitt's arguments on parallel developments within early-modern states: ever since Leviathan (1938), he sketched the dissolution of the classical constellation of internal peace and external ius belli both from within and without. Schmitt identified religious sects, secret societies and the republics of letters as 'indirect' political forces within states that transgressed the borderline between state and society and thus undermined state sovereignty. ${ }^{109}$ Liberal theorizing extended the logic of conflicts between private interests and sentiments to the global level in postulating a harmonious world society, thus blurring the ${ }^{107}$ Carl Schmitt, 'Staatliche Souveränität und freier Meer: Über den Gegensatz von Land und See im Völkerrecht der Neuzeit', [1941], in SGN, 401-30 (401, 405, 407, 414-5); Carl Schmitt, 'Das Meer gegen das Land', [1941], in SGN, 395-400 (396).

${ }^{108}$ Schmitt, 'Staatliche Souveränität', 407.

${ }^{109}$ Carl Schmitt, The Leviathan in the State Theory of Thomas Hobbes: Meaning and Failure of a Political Symbol, translated by George Schwab and Erna Hilstein (Westport, 1996[1938]), 71, 734; Carl Schmitt, Der Leviathan in der Staatslehre des Thomas Hobbes: Sinn und Fehlschlag eines politischen Symbols (Stuttgart, 2003[1938]), 113, 116-8. 
demarcation between internal and external and 'ideologising' also state war: rather than a cosmopolitan utopia, the result, Schmitt bitterly argued, was a 'global civil war' of intensified ideologies, reminiscent of the early-modern confessional strives rather than duel-like state war. ${ }^{110}$

For Schmitt, sovereignty, balance of power and contained land war lay on one side and ideological tensions, maritime war, judicial norms and civil war on the other. Schmitt's arguments here were, of course, empirically problematic in many respects, and schematic rather than properly historical and nuanced. ${ }^{111}$ Nevertheless, we can perceive in this period a change from the abstract theorizing of the political aspect of wars and warlike aspects of politics into an at least ostensibly chronological mode of argumentation. Containment was now an anterior European achievement, while intensification through maritime categories brought about its gradual dissolution. This historical sketch formed the backbone of The Nomos of the Earth, which also devoured many of Schmitt's Third Reich ideas, such as the land/sea opposition, the spatial nature of peace, the need to demarcate enemies from criminals and war from peace, the concepts of discriminating war and Großraum, and the nature of present wars as global civil wars, now set within a historical frame. ${ }^{112}$

${ }^{110}$ Schmitt, 'Turn to Discriminating Concept', 31, 69, 72 (518-19, 560, 562); Schmitt, Leviathan, 47-8, 58 (72-5, 89); Carl Schmitt, 'Die letzte globale Linie', [1943], in SGN, 441-52 (446).

${ }^{111}$ For the various criticisms, see Peter Schröder, 'Carl Schmitt's Appropriation of the Early Modern European Tradition of Political Thought on the State and Interstate Relations', History of Political Thought, 33:2, 2012, 348-71; Benno Teschke, 'Fatal Attraction: A Critique of Carl Schmitt's International Political and Legal Theory', International Theory, 3 (2011), 179-227; William E. Scheuerman, 'International Law as Historical Myth', Constellations, 11 (2004), 537550.

${ }^{112}$ Schmitt, Nomos, 55, 59, 122, 124, 259, 296, 309-13 (25, 28, 92, 94-5, 233, 271, 285-90). 
This historical sketch is crucial for correctly locating Clausewitz within Schmitt's theory. Based on his 1938 reading of Clausewitz as a theorist of land war, we can assume that Schmitt primarily included Clausewitz in the containment part of the narrative. In 1954, he repeated the note that Clausewitz only spoke of land warfare. ${ }^{113}$ Gradually, however, when he began to argue for Lenin's key role in the shift from state wars to civil war, Schmitt assigned Clausewitz a paradoxical position. ${ }^{114}$ This idea reappeared in the 1963 partisan theory where Schmitt located Clausewitz on an epochal threshold: Clausewitz had not only observed the emergence of partisanship and popular uprisings that spelled the downfall of classical war, but also indirectly contributed to this process by inspiring revolutionaries. For Schmitt, Clausewitz was the first to recognise the particularity of partisanship, yet unable to see where its logic would lead. Schmitt engaged with Clausewitz's call for defensive partisanship in Bekenntnisdenkschrift, but also connected the theory of the partisan with elements of Vom Kriege. Most importantly, Schmitt noted that Clausewitz's idea of war as the continuation of politics 'already contains in nuce a theory of the partisan whose logic has been followed to the end by Lenin and Mao'. ${ }^{115}$

At face value, the remark is surprising: first, because the continuity thesis emerged in Clausewitz's late instrumental theory, which described the overall framework of which partisan warfare was only an extension, and, second, because the dictum related to 'government', the third element in Clausewitz's trinity, rather than to the people whom Clausewitz only characterised with hatred and enmity, as noted by Schmitt himself. ${ }^{116}$ Schmitt thus seems to be linking Clausewitz's ideas quite freely and implying that the idea of continuity between politics and war worked both ways. While

${ }^{113}$ Carl Schmitt, 'Welt großartigster Spannung', [1954], in SGN, 513-7 (513).

${ }^{114}$ Carl Schmitt, 'Die letzte globale Linie', [1943], in SGN, 441-52 (447).

${ }^{115}$ Schmitt, Theory of the Partisan 8 (15).

${ }^{116}$ Ibid., 47 (51). 
he certainly took some interpretative liberties, Schmitt, however, arguably did not see the original continuity thesis per se as implying the reversed version, but only thought that this was the way it factually came to be interpreted by Marxian thinkers who sought to undermine the differences between political and military means in order to legitimise ideological battle. Clausewitz merely sowed 'seeds' for the dissolution of the policy/war divide, just as Hegel maintained in his conservative theory revolutionary 'sparks', which later became ideological weapons. ${ }^{117}$ Analogically with his non-Marxian reading of Hegel, Schmitt read Clausewitz as a serious theorist of contained conflicts whose work manifested the primacy and autonomy of the political, but who was himself drawn into political battle. While Clausewitz's intentions were far from revolutionary, the tensions in his work sparked a development that undermined state war. The role that Schmitt assigned to Clausewitz in his narrative of modernity-not that of the culprit, as interpreted by Slomp ${ }^{118}$ — was thus remarkably similar to that of Hobbes, whose concession to make faith a private matter in order to escape religious civil war and to rescue Christianity backfired, as the private sphere of society eventually turned into a locus of revolt and confessional strife returned in secularised form as modern revolutions. ${ }^{119}$

The figure of the partisan reflected these paradoxical historical tendencies. For Schmitt, the partisan acted in secrecy, and occasionally in civil clothes rather than openly, thereby obliterating the distinctions of regularity/irregularity and legality/illegality and aggravating the blurred ${ }^{117}$ Ibid., 48 (51-2).

${ }^{118}$ Gabriella Slomp, Carl Schmitt and the Politics of Hostility, Violence and Terror (Basingstoke, 2009), 94.

119 The point about the analogous position of Clausewitz and Hobbes in Schmitt's historical perception is made in slightly different terms in William Hooker, Carl Schmitt's International Thought: Order and Orientation (Cambridge, 2009), 175. 
intermediate state. ${ }^{120}$ Simultaneously, however, Schmitt depicted the partisan as having truly political enemies and reflecting the 'utmost intensity of political engagement'; ${ }^{121}$ thus he made partisanship a manifestation of the political in the era of liberal de-politicisation. The partisan was thus peculiarly situated between the poles of excessive intensification and totalisation of war, on the one hand, and the wishful eradication of enmity, on the other.

Schmitt's paradoxical affirmation of the partisan can be understood in light of a distinction that remained oblique, yet gave meaningful structure to his reception of Clausewitz in Theorie des Partisanen. In harmony with his earlier space-orientation, Schmitt demarcated between defending partisans tied to an area of land and mobile global revolutionaries. Schmitt claimed that the early nineteenth-century defending partisans that Clausewitz knew had real (wirklich) enemies and strong ties to the soil of their country and to the regular political order. ${ }^{122}$ For Schmitt, the figure of the legitimate partisan was a paradoxical outgrowth of the regular forms of war. Here, again, he followed closely in the footsteps of Clausewitz, for whom popular uprising could only be conceived of in the standard framework, as an extension of the logic of political war. ${ }^{123}$ Schmitt noted that despite theorising on absolute war, Clausewitz always presumed 'the regularity of a prevailing order of the state'. ${ }^{124}$ It was only the type of illegitimate revolutionary fighter, idealised by Lenin and Mao, that detached partisan warfare completely from classical limitations. With the erosion of state structure and the concomitant intensification and globalisation of ideological

${ }^{120}$ Schmitt, Theory of the Partisan, 16, 27, 37, 69- 70 (23, 33, 42, 72-3). See Slomp, Carl Schmitt, 83-4.

${ }^{121}$ Schmitt, Theory of the Partisan, 90 (92)..

${ }^{122}$ Ibid., 21-22, $92(27,93)$.

${ }^{123}$ Clausewitz, On War, 480 (522).

${ }^{124}$ Schmitt, Theory of the Partisan, 93 (94). 
contestation, defending partisans became revolutionary partisans who had only 'absolute' enemies. ${ }^{125}$

While resisting excessive intensification by the bond to land and simultaneously manifesting the political in the era of de-politicisation, the figure of the partisan was similarly located between two equally problematic images of war: between war as elimination and war as game. After making his standard point of traditional war as duel, Schmitt gave the analogy a surprisingly negative tone by speaking of cabinet wars as 'conventional play' in which the 'conventional enemy' became a mere 'adversary in a war game', until the Spanish guerrilla war of 1808-13 introduced partisanship and reasserted war's 'seriousness' and 'real enemies'. ${ }^{126}$ Again, the theoretical import of traditional partisans was legitimate; only the revolutionaries raised the intensity excessively and made enmity total. Once again we perceive a double exposure based on containment and intensification, and Clausewitzian arguments can be located on both sides. In post-war historical reality, Schmitt had accepted the structural changes in basic concepts, including a symptomatic scale of intensities. While in the self-declaredly 'political' pre-war view Schmitt maintained that war found its meaning in peace, now commenting on Mao's theory, he again noted that 'war has its meaning in enmity' and that 'on the basis of experience, peace also contains an element of potential enmity'. ${ }^{127}$ This is effectively to say that the original Clausewitzian continuity thesis had been reversed. This change, for Schmitt, marked an epochal shift from order to disintegration in the quasi-historical narrative and from containment to intensification in his own argumentation.

\footnotetext{
${ }^{125}$ Ibid., 22, 93 (27, 94).

${ }^{126}$ Ibid., 52, 88-90 (56, 90-2).

${ }^{127}$ Ibid., 59-60 (63).
} 
Readings of Schmitt and Clausewitz on the basis of the remarks in Theory of the Partisan invariably ignore what took Schmitt there: the intricate oscillation between containment and intensification arguments for almost half a century. However, Schmitt still had one more turn in store. Towards the end of his career, re-engaging with Clausewitz from this post-nation state perspective of partisanship and enmity, Schmitt rediscovered Clausewitz's Bekenntnisdenkschrift, which prioritised existential and intensifying factors over instrumentality and containment. $\mathrm{He}$ perceived this early text as containing elements for a truly political view of war, and, in commenting on popular uprising, the text of course linked primarily with the intensification of war. However, Schmitt read also this text with an ambiguous attitude, not by any means unequivocally celebrating Clausewitz's breakaway from limited state war but rather relating this emphasis to its historical and philosophical context and emphasizing Clausewitz's links with the traditional framework of contained war. While in Theory of the Partisan the containment argument was mostly blurred, its presence was more apparent in Schmitt's 1967 review on an edition of Clausewitz's miscellaneous writings, entitled "Clausewitz as a Political Thinker." ${ }^{128}$ Rather than a sustained argument, the essay provided fragmental historical glosses on Prussian animosity towards Napoleon as reflected in Clausewitz's 1812 Bekenntnisdenkschrift. Schmitt argued that Clausewitz's call for a Prussian popular uprising against Napoleon were shaped not only by his observations on the Spanish resistance in 1807-14 but also Fichte's open opposition to Napoleon. However, while Fichte's enmity was "ideological" and reflected his commitment to the closed commercial state, which Schmitt rather identified with a 'society', Clausewitz's enmity towards Napoleon was truly "political" in that it took the state as its starting point, particularly Clausewitz's "own concretely existing state." ${ }^{129}$ Clausewitz as "a true Prussian" considered only ${ }^{128}$ Carl Schmitt, 'Clausewitz als politischer Denker: Bemerkungen und Hinweise', Der Staat, 6 (1967), 479-502. ${ }^{129}$ Ibid., 500. 
land war rather than maritime war, but precisely because of this limitation was able to offer a genuinely Prussian antidote to Western interpretations of war and their problematic "revolutionary" sources of legitimacy. ${ }^{130}$ Clausewitz thus appeared to Schmitt as a restraining figure vis-à-vis the increasingly ideological warfare of the Napoleonic era. Instead of reiterating his containment arguments, Schmitt here merely attributed them to his French pupil Julien Freund, who had recently argued that Clausewitz's doctrine of war as the continuation of politics made wars constrainable precisely by introducing the political element. ${ }^{131}$ This was what Schmitt had been maintaining all along. Enmity and war were inevitable, Schmitt added, but what mattered was the "circumscription [Begrenzung] of war" so that even Clausewitzian "battles of destruction" would be waged between two organized armies instead of one half of the humankind destroying the other half in the name of humanity. ${ }^{132}$

This was a strong restatement of containment arguments, and reading Theory of the Partisan in the light of this late essay leaves a rather different impression than that of Schmitt simply celebrating partisanship as a contemporary manifestation of the political or underscoring the 'existential' significance of war. If we read only Schmitt's late paradoxical remarks on partisanship and combine these with the idiosyncratic Weimar theory of the political, it is easy to overemphasise the arguments of intensification and Schmitt's deviation from Clausewitz's political theory of war. After somewhat questionably interpreting Schmitt as 'glorifying' the belligerent human nature and seeing warfare as 'an existential mode', Beatrice Hanssen, for instance, concludes that Schmitt went 'against the interpretative tradition in Clausewitz scholarship' and 'emphasized not the instrumentality of warfare, but its role as the extreme instance of the decision ... about who counts

${ }^{130}$ Ibid., 496 and 501.

${ }^{131}$ Ibid. 500; Cf. Julien Freund, L'essence du politique (Paris, 1965), 595 and passim.

${ }^{132}$ Schmitt, 'Clausewitz als politischer Denker', 500. 
as a friend, who as a public enemy'. ${ }^{133}$ Citing The Concept of the Political, Hanssen, however, omits the passage where Schmitt explicitly underlined that the outbreak of war presupposed the anterior political decision regarding who the enemy was and that warfare thus merely implemented, rather than climaxed, the decision.

Furthermore, if we start with Schmitt's opaque affirmation of the partisan-a figure of the intermediate state — rather than the structures that partisan warfare allegedly obliterated, we can easily misconstrue Schmitt's relation to Clausewitz as regards peace and war, too. I have attempted to show that Schmitt consistently read Clausewitz as a classical theorist who demarcated peace from war, yet unintentionally contributed to their blurring. My interpretation thus contrasts with Gabriella Slomp's formulation that Schmitt 'denie[d] a stark separation between war and peace' or 'rejected the war-peace opposition' and that Clausewitz's idea of war as the continuation of politics by other means urged him to do so. ${ }^{134}$ On the contrary, in my reading, Schmitt—again like Clausewitz-was motivated to keep the two categories separate on a conceptual level, yet critically diagnosed the reasons for the impossibility of this in the modern world. Furthermore, the original idea of war as the continuation of politics by other means does not suggest such difficulties. The Clausewitzian dictum jeopardises the distinction of war and peace only if we either incorrectly attribute to Clausewitz's instrumental theory an ontological identification of politics and war (and a concomitant relativisation of peace) or implicitly, and equally incorrectly, we assume the continuity thesis to be identical with its reversed form.

\section{Conclusions}

\footnotetext{
${ }^{133}$ Hanssen, Critique, 23.

${ }^{134}$ Slomp, Carl Schmitt, 29, 94.
} 
Clausewitz and Schmitt both operated at the intersection of politics and warfare. Clausewitz emphasised the political nature of war and the role of warfare as an instrument of state policy, thus taking the two phenomena conceptually closer than what was customary in military studies in his time. Schmitt similarly attempted a novel conceptualisation by making war the exterior manifestation of the extreme position on a scale of political intensities.

Terminologically, Schmitt's 'political' referred, first, to the framework of the state in which both mundane and existential political matters were to be dealt with and, second, to the energy potential, reified as 'the political', that was inherently prone to transcend this framework. The political, being functionally equivalent with enmity in Clausewitz's trinity, was a source of intensification rather than order and containment. To counter this challenge Schmitt gradually built institutional and historical arguments involving balances of power, free mandates to wage wars overseas, and Großraum formations with their own groundings for law and war. For Schmitt, there were only political solutions to political problems, such as that of war. Particular edifices were needed so that wars would not become ideological and 'political' in the sense of intensification, but would remain 'political' in the sense of containment. The adjective 'political' in Schmitt's theory of political war must therefore be understood as carrying a double meaning and condensing the containment/intensification framework into a single word.

The analysis showed that despite theorising intensification and existential enmity, Schmitt did not significantly deviate from Clausewitz's framework of political war-a framework that emphasised intensifying factors and encompassed 'existential' aspects to begin with. Schmitt instead radicalised the element of wars being grounded in identity-forming decisions regarding the political enemy. That Schmitt here went beyond Clausewitz is trivial, given their dissimilar historical contexts. Schmitt's theory therefore should not be interpreted as 'a reversal of the 
primacy of policy in Clausewitz', ${ }^{135}$ but rather the continuation of the original political point in a radicalised form in the era of total war.

In framing the relationship between politics and war, Schmitt built on Clausewitz's continuity thesis, although sometimes rhetorically rejecting, sometimes affirming the formulation. The dictum is admittedly central for Clausewitz, but we should read it in light of Clausewitz's whole theory instead of perceiving Clausewitz in entirety through this prism. Similarly, if read in light of the dictum alone, Schmitt's relation to Clausewitz is liable to be misconstrued and his deviation from Clausewitz's allegedly instrumental theory in favour of an 'existential' view consequently overstated. The implicit reasoning in earlier scholarship is that in apparently rejecting the dictum, Schmitt must have discarded Clausewitz altogether. We should, however, rigorously differentiate original ideas from stock phrases that often attain lives of their own, thus enabling their adoption for various purposes. These are two different histories of reception, and the latter should not eclipse the former. The perplexing instability of Schmitt's argumentation on the linguistic level becomes comprehensible only if we differentiate between containment and intensification arguments, observe chronological shifts of emphasis, and pay attention to specific argumentative contexts.

${ }^{135}$ Dodd, Violence and Phenomenology, 45. 